\title{
PARACOCCIDIOIDOMYCOSIS IN CHILDREN: CLINICAL PRESENTATION, FOLLOW-UP AND OUTCOME
}

\begin{abstract}
SUMMARY
From February, 1981 to May, 2001, 63 children under 15 y old (ages $2-15$ y, median $=8$ y, mean \pm 1 SD $=8 \pm 3$ y) presenting 70 episodes of Paracoccidioidomycosis were admitted. The main clinical manifestations and laboratory features observed upon admission were: lymph node enlargement (87.1\%), fever (75.7\%), weakness (48.6\%), pallor (41.4\%), hepatomegaly (40\%), splenomegaly $(35.7 \%)$, anemia (90\%), hypergammaglobulinemia $(88.5 \%)$, eosinophilia $(75.5 \%)$ and hypoalbuminemia (72.5\%). Moderate to severe malnutrition was detected in $35.7 \%$ of the episodes (Gomez's criterion). Radiographic and technetium studies showed bone lesions in 20 of the episodes, most of them being multiple lytic lesions, involving both long (70\%) and plain bones (30\%). First line treatment consisted of an association of sulfametoxazole-trimethoprin, which was used, exclusively, in 50 episodes. Follow-up of hemoglobin levels, number of eosinophils in the peripheral blood, albumin and gammaglobulin serum levels revealed significant sequential improvement one and six months after hospital admission, being quite useful to evaluate treatment effectiveness. Six patients died (9.3\%) and four developed sequelae (6.3\%). In conclusion, the juvenile and disseminated forms can be observed in about $70 \%$ of the episodes of PCM occurring in children younger than $15 \mathrm{y}$ old, most of them presenting with a febrile lymphoproliferative syndrome associated to anemia, eosinophilia and hypergammaglobulinemia.
\end{abstract}

KEYWORDS: Paracoccidioidomycosis; Paracoccidioides brasiliensis; Children; Eosinophilia; Hypergammaglobulinemia; Sulfametoxazole-trimethoprin.

\section{INTRODUCTION}

Paracoccidioidomycosis (PCM) is a granulomatous disease caused by Paracoccidioides brasiliensis. It was originally described by Lutz in 1908 and firstly observed in children by Montenegro, in $1911^{26}$. PCM is the most important mycosis of Latin America, the endemic area being centered in Brazil, especially in the Southern and Southeastern regions ${ }^{4}$ $5,11,18,23,25$. Approximately 50 cases have already been described in North America and other countries. All patients had visited or previously lived in one of the countries where PCM is endemic ${ }^{1,13}$.

The natural habitat of $P$. brasiliensis has not yet been defined, although epidemiological data suggest that the fungus lives in the soil $1^{5,8,19}$. More than $95 \%$ of the cases occur in adults, probably secondary to the long latency period of PCM, as demonstrated by the nonautochthonous cases reported outside the endemic areas ${ }^{1}$.

The lack of published reports about this disease in children ${ }^{2-3,6,9,11,15-}$ 17,22 prompted us to report our experience with 63 children less than $15 \mathrm{y}$ old who presented 70 episodes of PCM, admitted to the University Hospital of the State University of Campinas (UNICAMP), São Paulo, Brazil.

\section{PATIENTS AND METHODS}

The hospital records of 63 patients who had a confirmed diagnosis of PCM, were prospectively collected over a 21-year-period (February, 1981- May, 2001). The following data were analyzed: age, gender, complaint, signs and symptoms, laboratory features [hemogram, serum protein electrophoresis, aspartate aminotransferase (AST), alanine aminotransferase (ALT), gamma glutamyl transpeptidase $(\gamma-\mathrm{GT})$, serum bilirubin and bone marrow examination] imaging studies (radiographic, ultrasonographic and technetium bone scans), treatment regimen, complications and outcome.

The protein-energy malnutrition diagnosis was established according to Gomez's graduation criterion ${ }^{12}$ that estimates the weight deficit in relation to age. The National Center for Health Statistics (NCHS) curves were used for comparison ${ }^{14}$.

PCM presentation was considered as disseminated when more than one organ was affected, or if more than two lymph node chains were involved. If a sole organ and not more than two lymph node chains were affected the case was diagnosed as the localized form of PCM. Search 


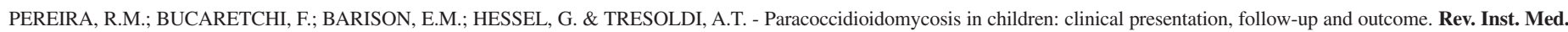
trop. S. Paulo, 46(3):127-131, 2004.

for associated diseases was performed only when the clinical condition was not improved by the employed treatment.

Hepatic abnormalities associated with PCM were considered when hepatomegaly was detected by physical examination or by abdominal ultrasonography, or by an increase in the levels of ALT, AST and $\gamma$-GT enzymes over reference values. The demonstration of the fungus in liver biopsy samples was also considered as an indicative of positive hepatic involvement.

Anemia was defined as an hemoglobin level lower than $12.0 \mathrm{~g} / \mathrm{dl}$; eosinophilia as more than 500 cells $/ \mathrm{mm}^{3}$ in the peripheral blood; hypoalbuminemia as albumin levels lower than $3.5 \mathrm{~g} / \mathrm{dl}$; and hyper gammaglobulinemia as gammaglobulin levels higher than $1.8 \mathrm{~g} / \mathrm{dl}$.

A database was constructed to evaluate the frequency distribution of the variables studied, using the SPSS for Windows 10.0 software. Comparison of variables was evaluated using the Mann-Whitney and Wilcoxon's non-parametrical tests. The distribution of hemoglobin levels and number of eosinophils in the peripheral blood, albuminemia and gammaglobulinemia are shown as a box and whisker plots. In each plot, the upper and lower short horizontal lines indicate the maximum and minimum values observed, respectively. The median, first and third quartiles of the values of each group correspond to the intermediate, lower and upper horizontal lines used to construct each rectangle, respectively. A p value $<0.05$ was considered to indicate significance.

\section{RESULTS}

Seventy episodes of PCM were diagnosed in 63 children (ages 2 y $15 \mathrm{y}$, median $=8 \mathrm{y}$, mean $\pm 1 \mathrm{SD}=8 \pm 3 \mathrm{y}$ ), with a male:female ratio of $1.3: 1$. When only children older than 12 y old were considered $(\mathrm{N}=13)$, a male:female ratio of 5.5:1 was observed. Four patients presented more than one episode of PCM. In $35.7 \%$ of the 70 episodes, patients showed moderate to severe malnutrition ( grade $\mathrm{II}=24.3 \%$ and grade $\mathrm{III}=11.4 \%$ ) upon admission. Forty-eight children were Caucasians, and there were no Asian children. By the time diagnosis was established most were living in urban areas $(\mathrm{N}=47 / 63,74.6 \%)$. Forty-four percent of the patients came from Campinas' metropolitan region, $30 \%$ from the southern part of the State of Minas Gerais, and 26\% others came from other cities of the State of São Paulo. More epidemiological data was not available.

In all 70 episodes, diagnosis was confirmed by the identification of Paracoccidioides brasiliensis in lymph node biopsy (84\%), bone biopsy (9\%) or skin biopsy (7\%). Most patients showed disseminated forms (53/70 episodes, $70 \%$ ), with localized forms being observed in 17 episodes.

The complaints that prompted children to seek medical care and motivated their admission had lasted, on average, $60 \mathrm{~d}$ (15 d- $1 \mathrm{y}$, Table 1). There was no significant difference considering the duration of complaints between the groups of children with disseminated and localized forms (Mann-Whitney test, $\mathrm{p}=0.3$ ).

The main clinical manifestations found at the moment of admission are summarized in Table 2. Lymph node enlargement was the most frequent clinical manifestation; in 35 episodes only lymph node
Table 1

Duration of complaints before hospital admission, in 63 children under $15 \mathrm{y}$ old who developed 70 episodes of Paracoccidioidomycosis, related to the number of episodes

\begin{tabular}{cc}
\hline Duration of complaint (days) & Number of episodes $(\%)$ \\
\hline$<60$ & $43(61.5)$ \\
$61-120$ & $17(24.3)$ \\
$121-180$ & $4(5.7)$ \\
$181-360$ & $6(8.5)$ \\
\hline
\end{tabular}

involvement was observed. As complications of lymphatic involvement, three patients presented intestinal obstruction, and two had proteinloosing enteropathy, caused by intestinal lymphangiectasy, which improved with the treatment for PCM. The most common skin lesion was of the verrucous type, although some children presented lesions that looked like molluscum contagiosum.

Table 2

The main clinical manifestations observed at the hospital admission, in 63 children under $15 \mathrm{y}$ old who developed 70 episodes of Paracoccidioidomycosis

\begin{tabular}{lcc}
\hline Clinical manifestation & Number & $\%$ \\
\hline Lymph node enlargement & 61 & 87.1 \\
Fever & 53 & 75.7 \\
Weight loss & 53 & 75.7 \\
Weakness & 34 & 48.6 \\
Pallor & 29 & 41.4 \\
Hepatomegaly & 28 & 40.0 \\
Splenomegaly & 25 & 35.7 \\
Osteoarticular pain or tumefaction & 14 & 20.0 \\
Jaundice & 9 & 12.9 \\
Cutaneous lesions & 7 & 10.0 \\
Lymph node fistulization & 7 & 10.0 \\
Abdominal pain & 5 & 7.1 \\
\hline
\end{tabular}

In 45 episodes of PCM, bone involvement was investigated (radiographic bone survey in 17, technetium bone scan in 14 and both in 14) and it was present in 20, consisting of multiple lytic lesions, in sixteen of them. Four patients showed a solitary bone lesion in the femur, which caused their sole clinical manifestation: painful movement of the thigh. Both long $(14 / 20,70 \%)$ and plain bones $(6 / 20,30 \%)$ were involved. Among the 14 patients undergoing both radiographic and technetium investigations, three showed lesions only in the technetium bone scan.

Enlarged hilar lymph nodes were the main findings of chest radiography $(24 / 64,37.5 \%)$. Only one of the patients showed pulmonary involvement, characterized by bilateral diffuse heterogeneous opacity. Abdominal ultrasonography performed in 55 episodes revealed $11(20 \%)$ normal results; lymph node enlargement (mainly peri-liver, peri-spleen and mesenteric) in $42(76.4 \%)$, homogeneous hepatomegaly in $33(60 \%)$ and splenomegaly in $19(34.5 \%)$.

The most frequent laboratory findings at admission were: anemia 63/70 (90\%), hyper gammaglobulinemia 62/70 (88.5\%), eosinophilia 
53/70 (75.5\%) and hypoalbuminemia 50/69 (72.5\%). Figure 1 shows the evolution of those laboratory parameters in the different time points of the study (admission, one and six months post-admission) in 30 episodes, where complete data was available.
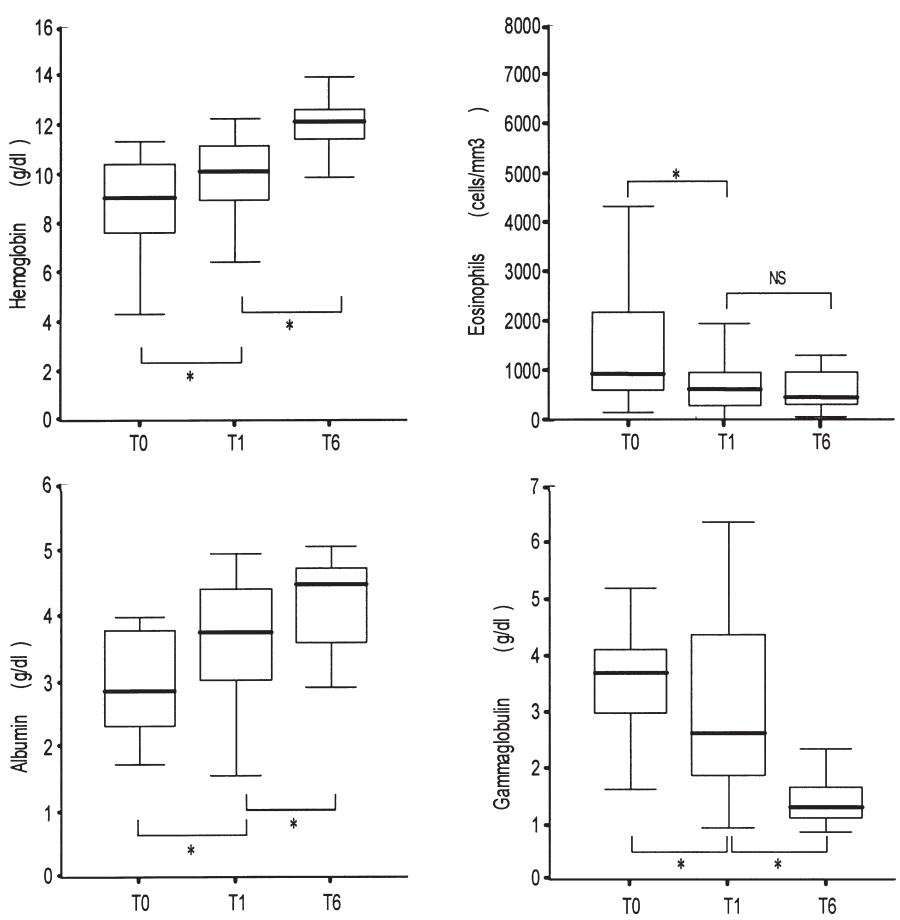

Fig. 1 - Box-plots of: hemoglobin and number of eosinophils in the peripheral blood; albumin and gammaglobulin serum levels, different time points. T0, $1^{\text {st }}$ day of hospital admission; T1 and T6, one and six months after hospital admission, respectively; NS = not significant; * $\mathrm{p}$ $<0.01$ (Wilcoxon test).

Some patients presented a slight increase of ALT and AST (9/45, $20 \%), \gamma$-GT $(8 / 26,30.7 \%)$ and direct bilirubinemia $(8 / 18,44.4 \%)$ levels. Bone marrow examination was performed in eight patients, showing fungus in five and hypo cellular condition in three.

Associated disease was found in only one child in whom lung tuberculosis was diagnosed during the second month of treatment of PCM.

Different therapeutic regimens were employed to treat specifically the PCM: sulfametoxazole-trimethoprin was used in $96 \%$ of the patients, as the sole drug in 50 patients $(71.5 \%)$ or associated to amphotericin B $(9 / 70,13 \%)$, ketoconazole $(5 / 70,7 \%)$, amphotericin B and ketoconazole $(2 / 70,3 \%)$ or itraconazole $(1 / 70,1.5 \%)$. Two patients were treated only with amphotericin $\mathrm{B}$ and one with ketoconazole. The mean duration of the treatment (attack plus maintenance) was 18 months (from 12 to 36 months). Leucopenia $\left(<5,000\right.$ leucocytes $\left./ \mathrm{mm}^{3}\right)$ secondary to the use of sulfametoxazole-trimethoprin occurred in 12 episodes, and was controlled by folinic acid administration, with no need of changing the therapeutic regimen. Recovery of nutritional status occurred in all cases after beginning the treatment.

There were six deaths (9.5\% of the patients), all of them in patients with severe disseminated forms of PCM. Five of those patients presented malnutrition. Deaths occurred between the 2 nd and the $28^{\text {th }}$ hospitalization day $($ median $=14 \mathrm{~d})$. There was no significant association between duration of symptoms and lethal outcome $(\mathrm{p}=0.5)$. Five of these patients were treated with amphotericin $\mathrm{B}$, as the sole drug $(\mathrm{N}=2)$ or associated with sulfametoxazole-trimethoprin ( $\mathrm{N}=3)$. Necropsy (performed in five patients), confirmed fungus' dissemination in all patients: lymph nodes, spleen, liver, bone marrow, bones and skin in all cases; lungs (4/5); small bowel (2/5); kidneys (1/5); pancreas (1/5); heart (1/5); tongue (1/5); tonsils (1/5) and testicles (1/5). No other infectious agent or associated complication was present, suggesting that death was likely caused by the fungal infection.

Fifty patients are being followed in the outpatient clinic; thirty-six have completed the treatment, while fourteen are still under treatment. Two of these last patients relapsed after abandoning treatment during its first semester. Seven patients were lost to follow up after showing an initial improvement in both clinical and laboratory parameters.

Complications of the disease occurred in four patients (6.3\%). Three developed portal hypertension. In one of them, an associated cholelithiasis had to be treated by cholecystectomy after the end of the PCM treatment. Another patient developed a huge splenomegaly associated with severe hyperesplenism, and had to have its spleen removed six months after the beginning of the treatment.

\section{DISCUSSION}

Although positive skin tests with paracoccidiodin occur with the same frequency in adult men and women, the clinical form appears to have a definite preponderance in males (male:female ratio of $15: 1$ ). That discrepancy has been related to the presence of estrogen-dependent immune factors, which block the transformation of the mycelium-toyeast form. The absence of these factors in children may help to explain why the male:female ratio of clinical PCM is close to $1: 1^{5,18,19}$ in this group of patients. A higher frequency among male patients above $12 \mathrm{y}$ old, who had already initiated pubertal development, was also observed in this study.

Duration of symptoms before the diagnosis and the clinical manifestations of PCM were similar to other studies ${ }^{2-3,6,9,11,15-17}$. Most of the clinical manifestations were related to the reticuloendothelial system, especially lymph node enlargement, hepatomegaly and splenomegaly.

Severe malnutrition, which may jeopardize cellular immunity, has been implicated by some into triggering the disease ${ }^{20,29}$. However, the low frequency of children with severe malnutrition observed in the present study and the complete recovery of nutritional status after treatment, suggest that the malnutrition may be secondary to the PCM.

Hepatic abnormalities associated with PCM occurred in almost half of the episodes. The increase in $\gamma$-GT and direct bilirubin levels may suggest, in some cases, the occurrence of an obstructive jaundice, caused by enlargement of the hilar lymph node ${ }^{7}$.

Despite the characteristics of the bone lesions being similar to those previously reported ${ }^{6,15-16,28}$, a more frequent bone involvement was observed in the present study. This may be related to the use of technetium bone scan in a great number of cases. As observed, this scan was able to diagnose small bone lesions that were not detected by conventional 
radiology.

As suggested by the necropsy findings, the frequency of pulmonary parenchyma lesions may be under reported, especially in the disseminated forms. Although speculative, more accurate data could result from searching the fungus in the bronchoalveolar lavage.

Bone marrow examination was performed in eight patients who were initially referred to a pediatric oncology service, with a presumed diagnosis of leukemia or lymphoma. Although this procedure has helped to confirm the diagnosis of PCM, it is our belief that it should not be performed routinely in these cases.

The laboratory findings (anemia, eosinophilia, hypoalbuminemia and hyper gammaglobulinemia) upon hospital admission did not differ from elsewhere reported ${ }^{10,15}$. In addition, the present results show significant sequential improvement of the laboratory data one and six months after hospital admission. The follow up with these parameters is simple and quite useful to evaluate the effectiveness of the treatment.

PCM treatment should last for a long time, since its premature interruption leads to a high relapse rate. This is demonstrated by the occurrence of relapse in both children who abandoned treatment during the first six months, and suggests that the other relapsing cases may be due to an insufficient period of treatment. However, there is no consensus concerning the adequate period of treatment for children with PCM, which may last from six months to two years ${ }^{21,24}$. The association of sulfametoxazole-trimethoprin has been considered to be the first option for the treatment of PCM, since it is well tolerated and associated with few side effects. The effectiveness of this association is over $80 \%$. Moreover, it is inexpensive, may be infused intravenously in the severe forms of PCM, it is easy to administer orally and it is available in public health services. According to some, failures of treatment with this association are mostly secondary to poor patient compliance ${ }^{19,24,27,30}$.

The frequency of deaths herein reported did not differ from the one observed in other reported series of PCM in children ${ }^{6}$, despite the use of amphotericin $\mathrm{B}$ and adequate supportive measures in the vary severe cases. Deaths may be attributed to the severity of the disseminated forms of PCM in some children, probably immunocompromised by both PCM and malnutrition ${ }^{20,25,29}$.

In conclusion, the diagnosis of juvenile and disseminated forms of PCM should always be considered in children younger than $15 \mathrm{y}$ old, coming from regions where PCM is endemic and presenting with a febrile lymphoproliferative syndrome, associated to anemia, hyper gammaglobulinemia and eosinophilia. Early diagnosis and institution of appropriate treatment is essential to achieve adequate control of this disease. Empirical treatment should be considered in severe disseminated forms, while laboratory studies to confirm PCM are being conducted.

\section{RESUMO}

\section{Paracoccidioidomicose em crianças: apresentação clínica, seguimento e evolução}

Foram analisados 70 episódios de Paracoccidioidomicose em 63 crianças com menos de 15 anos de idade (variação de 2 a 15 anos, mediana
$=8$ anos, média $\pm 1 \mathrm{DP}=8 \pm 3$ anos), no período de fevereiro de 1981 a maio de 2001. As principais manifestações clínicas e alterações laboratoriais à admissão foram: linfonodomegalia $(87,1 \%)$, febre $(75,7 \%)$, fraqueza $(48,6 \%)$, palidez $(41,4 \%)$, hepatomegalia $(40,4 \%)$, esplenomegalia $(35,7 \%)$, anemia $(90 \%)$, hipergamaglobulinemia $(88,5 \%)$, eosinofilia $(75,5 \%)$ e hipoalbuminemia $72,5 \%$. À admissão, $35,7 \%$ das crianças apresentavam desnutrição moderada e grave (critério de Gómez). Os resultados de radiografia simples e cintilografia óssea revelaram lesões ósseas em 20 episódios, a maioria constituída de lesões múltiplas e líticas, envolvendo ossos longos (70\%) e planos (30\%). A droga de escolha para o tratamento foi a associação sulfametoxazoltrimetoprina, sendo empregada isoladamente em 50 episódios. O seguimento de alguns resultados laboratoriais (dosagem de hemoglobina e contagem de eosinófilos no sangue periférico, dosagem de albumina e gamaglobulina séricas) revelou melhora significativa após o $1^{\circ}$ e $6^{\circ}$ mês da admissão, sendo muito útil para avaliação da eficácia terapêutica. Quatro pacientes evoluíram com seqüelas (6,3\%) e seis (9,3\%) morreram. Pode-se concluir que as formas juvenil e disseminada da PCM são prevalentes em crianças menores que 15 anos, ocorrendo em $70 \%$ dos episódios, apresentando-se como uma síndrome linfoproliferativa febril associada a anemia, eosinofilia e hipergamaglobulinemia.

\section{ACKNOWLEDGMENTS}

To Prof. Dr. Joaquim Murray Bustorff da Silva, for reviewing the English text.

\section{REFERENCES}

1. AJELLO, L. \& POLONELLI, L. - Imported paracoccidioidomycosis: a public health problem in non-endemic areas. Europ. J. Epidem., 1: 160-165, 1985.

2. BARBOSA, G.L. - Paracoccidioidomicose na criança. Rev. Pat. trop., 21: 269-383, 1992.

3. BENARD, G.; ORII, N.W.; MARQUES, H.H.S. et al. - Severe acute paracoccidioidomycosis in children. Pediat. infect Dis. J., 13: 510-515, 1994.

4. BLOTTA, M.H.S.L; MAMONI, R.L.; OLIVEIRA, S.J. et al. - Endemic regions of paracoccidioidomycosis in Brazil: a clinical and epidemiologic study of 584 cases in the southeast region. Amer. J. trop. Med. Hyg., 61: 390-394, 1999.

5. BRUMMER, E.; CASTAÑEDA, E. \& RESTREPO, A. - Paracoccidioidomycosis: an update. Clin. Microbiol. Rev., 6: 89-117, 1993.

6. CASTRO, R.M. \& DEL NEGRO, G. - Particularidades clínicas da paracoccidioidomicose na criança. Rev. Hosp. Clín. Fac. Med. S. Paulo, 31: 194-198, 1976.

7. CHAIB, E.; OLIVEIRA, C.M.C.; PRADO, P.S. et al. - Obstructive jaundice caused by blastomycosis of the lymph nodes around the common bile duct. Arq. Gastroent. (S. Paulo), 25: 198-202, 1988.

8. CONTI-DIAZ, A. \& RILLA, F.D. - Hipotesis sobre el nicho ecológico da Paracoccidioides brasiliensis. Rev. med. Urug., 5: 97-103, 1989.

9. FARHAT, C.K.; RAYMUNDO, M.E.C.; GASPAR, J. M. et al. - Paracoccidioidomicose na criança: relato de dois casos. J. Pediat. (Rio de J.), 60: 226-231, 1986.

10. FIORILLO, A.M. \& MARTINEZ, R. - Exames complementares. In: DEL NEGRO, G.; LACAZ, C.S. \& FIORILLO, A.M., ed. Paracoccidioidomicose. Blastomicose Sul Americana. São Paulo, Sarvier; EDUSP, 1982. p. 265-269.

11. FONSECA, E.R.S.; PARDAL, P.P.O. \& SEVERO, L.C. - Paracoccidioidomycosis in children in Belém, Pará State, Brazil. Rev. Soc. bras. Med. trop., 32: 31-35, 1999. 
12. GOMEZ, F. - Desnutrición. Bol. méd. Hosp. infant. (Mex.), 3: 543-551, 1946.

13. GREER, D. L. \& RESTREPO, A. - La epidemiologia de la paracoccidioidomicosis. Bol. Ofic. sanit. panamer., 83: 428-445, 1977.

14. HAMILL, P.V.; DRIZD, T.A.; JOHNSON, C.L.; REED, R.F. \& ROCHE, A.F. - NCHS Growth curves for children birth-18 years. United States. Vital Hlth. Statist., 11(165): 1-74, 1977.

15. HILDEBRAND, T.M; ROSÁRIO FILHO, N.A; TELLES FILHO, F.Q. et al. Paracoccidioidomicose na criança: aspectos clínicos e laboratoriais em 25 casos. J. Pediat. (Rio de J.), 63: 92-97, 1987.

16. LONDERO, A.T.; RIOS-GONÇALVES, A.J.; TERRA, M.F.G. \& NOGUEEIRA, S.A. Paracoccidioidomycosis in Brazilian children: a critical review (1911 - 1994). Arq. bras. Pediat., 4: 128-137, 1997.

17. LONDERO, A.T. \& MELO, I.S. - Paracoccidioidomycosis in childhood. A critical review. Mycopathologia (Den Haag), 82: 49-55, 1983.

18. MARQUES, S.A; FRANCO, M.; MENDES, R.P. et al. - Aspectos epidemiológicos da paracoccidioidomicose na área endêmica de Botucatu (São Paulo, Brasil). Rev. Inst. Med. trop. S. Paulo, 25: 87-92, 1983.

19. MARQUES, S.A. - Paracoccidioidomicose: atualização epidemiológica, clínica e terapêutica. An. bras. Derm., 78: 135-150, 2003.

20. McMURRAY, D.N.; LOOMIS, S.A.; CASAZZA, L.J.; REY, H. \& MIRANDA, R. Development in impaired cell-mediated immunity in mild to moderate malnutrition. Amer. J. clin. Nutr., 34: 68-77, 1981.

21. MENDES, R.P.; NEGRONI, R. \& ARECHAVALA, A. - Treatment and control of cure In: FRANCO, M.; LACAZ, C.S.; RESTREPO, A. \& DEL NEGRO, G. Paracoccidioidomycosis. Boca Raton, CRC Press, 1994. p. 373-392.

22. OCHOA, M.T.; FRANCO, L. \& RESTREPO, A. - Características de la paracoccidioidomicosis infantil: informe de cuatro casos. Medicina U.P.B. (Medellín), 10: $97-108,1991$.
23. PANIAGO, A.M.M.; AGUIAR, J.I.A.; AGUIAR, E.S. et al. - Paracoccidioidomicose estudo clínico e epidemiológico de 422 casos observados no Estado de Mato Grosso do Sul. Rev. Soc. bras. Med. trop., 36: 455-459, 2003.

24. REIS, J.A. \& COLOMBO, A.L. - Paracoccidioidomicose. In: FARHAT, C.K CARVALHO, E.S.; CARVALHO, L.H.F.R. \& SUCCI, R.C.M. Infectologia pediátrica. São Paulo, Atheneu, 1999. p. 524-528.

25. RESTREPO, A. - Paracoccidioidomycosis. In: FEIGIN, R.D. \& CHERRY, J.D. Textbook of pediatric infectious diseases. Philadelphia, W.B. Saunders, 1992. p. 1928-1934.

26. RESTREPO A. - Paracoccidioides brasiliensis. In: MANDELL, G.L.; DOUGLAS, R.G \& BENNETT, J.E. Principles and practice of infectious diseases. New York, Churchill Livingstone, 2000. p. 2768-2772.

27. RESTREPO, A. \& ARANGO, M.D. - In vitro susceptibility testing of Paracoccidioides brasiliensis to sulfonamides. Antimicrob. Agents Chemother., 18: 190-194, 1980.

28. ROSÁRIO FILHO, N.A.; TELLES FILHO, F.Q.; COSTA, O. \& MARINONI, L.P. Paracoccidioidomycosis in children with different skeletal involvement. Rev. Inst. Med. trop. S. Paulo, 27: 337-340, 1985.

29. SMYTHE, P.M.; BRERETON-STILES, G.G.; GRACE, H.J. et al. - Thymolymphatic deficiency and depression of cell mediated immunity in protein-calorie malnutrition. Lancet, 2: 939-943, 1971.

30. STEVENS, D.A. \& VO, P.T. - Synergistic interaction of trimethoprin and sulfamethoxazole on Paracoccidioides brasiliensis. Antimicrob. Agents Chemother., 21: 852-854, 1982

Received: 15 August 2003

Accepted: 19 May 2004 